\section{Phosphorus Availability in Some Acid Soils Influences Bentgrass and Annual Bluegrass Growth}

\author{
S. Kuo, S.E. Brauen, and E.J. Jellum \\ Washington State University Puyallup Research and Extension Center, \\ Puyallup, WA 98371-4998
}

Additional index words. clipping yield, phosphorus uptake, phosphorus soil test, Poa annua, Agrostis palustris

Annual bluegrass (Poa annua L.) is usually considered a weed in turf. Phosphorus fertilization has been implicated in infestations of annual bluegrass in turf, as high and repeated $\mathrm{P}$ fertilizer application increases growth and density of annual bluegrass in bentgrass stands (Goss et al., 1975). Application of $\mathrm{S}$ to acidify soil or limited or no $\mathrm{P}$ application has been recommended, because reduced $\mathrm{P}$ availability can decrease annual bluegrass density (Goss et al., 1975). However, nothing is known about the relationship between available soil $\mathrm{P}$ and the growth of bentgrass and annual bluegrass in acid soils. The objective of this experiment was to determine the growth responses of bentgrass and annual bluegrass to $\mathrm{P}$ over a wide range of available $P$ levels using 21 acid soils collected from various locations in western Washington.

The soils were air-dried and crushed to pass through a 2-mm sieve. Soil chemical characteristics determined included $\mathrm{pH}$ (4.67 $\pm 0.56 \mathrm{SD})$ [1 soil : 2 water $(\mathrm{w} / \mathrm{v})$ ratio], organic matter $(5.82 \pm 4.74 \%$ SD), oxalateextractable Al $\left(171.6 \pm 139.4 \mathrm{mmol} \cdot \mathrm{kg}^{-1}\right.$ $\mathrm{SD})$ and $\mathrm{Fe}\left(151.4 \pm 96.8 \mathrm{mmol} \cdot \mathrm{kg}^{-1} \mathrm{SD}\right)$ (Khalid et al., 1977). Each soil was mixed with $220 \mathrm{~kg} \mathrm{~K} / \mathrm{ha}$ as $\mathrm{KCl}$, placed in coneshaped pots (6-cm i.d., $25 \mathrm{~cm}$ long) and replicated three times. Bach pot was fertilized with $1 \mathrm{ml}$ of nutrient solution containing 0.26 $\mathrm{M} \mathrm{N}$ as $\mathrm{NH}_{4} \mathrm{NO}_{3}$ and $\left(\mathrm{NH}_{4}\right)_{2} \mathrm{SO}_{4}, 3.6 \times 10^{-5}$ $\mathrm{M} \mathrm{MnCl}_{2}, 2.6 \times 10^{-4} \mathrm{M} \mathrm{ZnSO}_{4}, 1.2 \times 10^{-4}$ $\mathrm{M} \mathrm{CuSO}_{4}, 6.8 \times 10^{-4} \mathrm{M} \mathrm{H}_{3} \mathrm{BO}_{3}, 3.5 \times$ $10^{-6} \mathrm{M} \mathrm{H}_{3} \mathrm{MoO}_{3}$, and $2.3 \times 10^{-2} \mathrm{M} \mathrm{MgSO}_{4}$, and seeded with $\approx 80$ seeds of annual bluegrass or 'Penncross' creeping bentgrass (Agrostis palustris Huds.). The pots were arranged in a completely randomized design and watered twice daily to maintain the soil

Received for publication 26 Apr. 1991. Accepted for publication 27 Dec. 1991. Washington State Univ. Research and Extension Center, Puyallup, WA 98371-4998. Scientific Paper no. 91-01-15. Dept. of Crop and Soil Sciences, Washington State Univ., College of Agriculture and Home Economics, Research Center, Washington State Univ., Pullman, WA 99164-6420. The cost of publishing this paper was defrayed in part by the payment of page charges. Under postal regulations, this paper therefore must be hereby marked advertisement solely to indicate this fact. moisture level at field capacity. The greenhouse was maintained at $21 \pm 1 \mathrm{C}$, and daylight was supplemented by metal halide lights for $16 \mathrm{~h} \cdot \mathrm{day}^{-1}$, with a photon flux density ranging from 500 to 900 $\mu \mathrm{mol} \cdot \mathrm{m}^{-2} \cdot \mathrm{s}^{-1}$, depending on the location on the bench.

The grass was clipped 3 to $5 \mathrm{~mm}$ above the soil surface, beginning 4 weeks after seeding, and then weekly for 12 weeks. The clippings were oven-dried at $65 \mathrm{C}$ for $48 \mathrm{~h}$, and the cumulative dry matter yields were determined. There was no apparent edge effect, despite the small container size. A por-
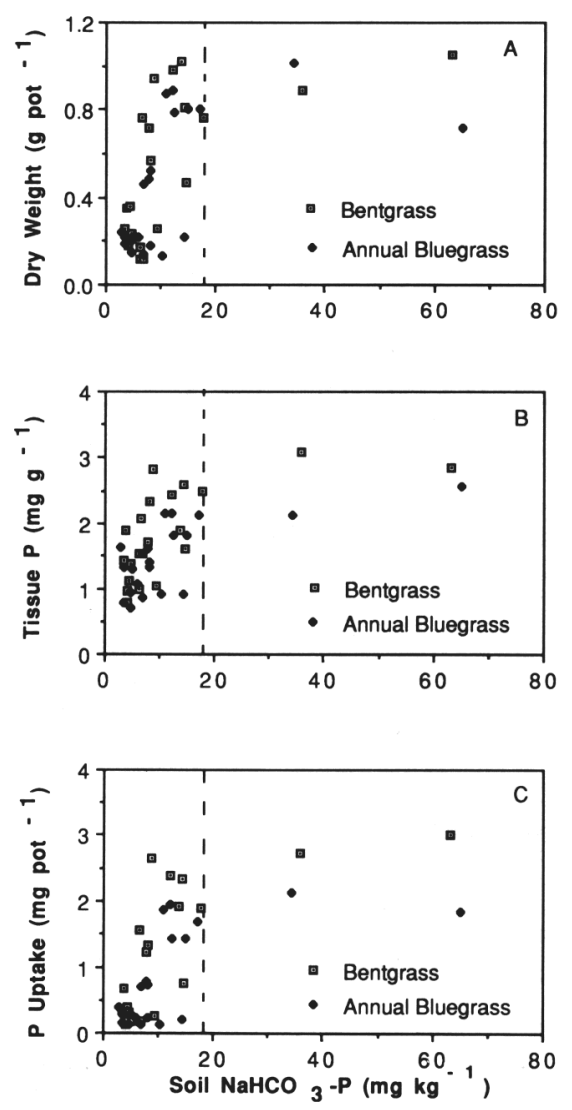

Fig. 1. The effect of $\mathrm{NaHCO}_{3}$-extractable $\mathrm{P}$ levels of 21 acid soils on (A) dry weights of clippings, (B) tissue $P$ concentration, and $(C) P$ uptake for bentgrass and annual bluegrass. The intercept of the vertical line on the X-axis represents the critical $\mathrm{NaHCO}_{3}$-extractable $\mathrm{P}$ level. tion of the clippings was digested in $\mathrm{HNO}_{3}$ $\mathrm{HClO}_{4}$ acids before $\mathrm{P}$ analysis (Murphy and Riley, 1962). Soil samples from the pots were analyzed for $\mathrm{NaHCO}_{3}$-extractable P (Olsen and Sommers, 1982). The graphical method of Cate and Nelson (1965) was used to determine the critical available $\mathrm{P}$ level for optimum growth. The method divides the $\mathrm{X}$ Y scatter diagram into four quadrants, maximizing the number of points in the positive quadrants (lower left and upper right) while minimizing the number in the negative quadrants. The point where the vertical line crosses the $\mathrm{X}$-axis is defined as the critical soil test level.

The response pattern for the relationship between clipping yield (expressed as dry weight) of bentgrass and annual bluegrass and available soil $\mathrm{P}$ by $\mathrm{NaHCO}_{3}$ extraction (Fig. 1A) was similar to that for Kentucky bluegrass (Poa pratensis L.) in a soil with very low available $\mathrm{P}(1.1 \mathrm{mg} \mathrm{P} / \mathrm{kg}$, Bray-1) (Hall and Miller, 1974). Clipping yields, tissue $\mathrm{P}$ concentration (Fig. 1B), and $\mathrm{P}$ uptake (Fig. 1C) for bentgrass and annual bluegrass responded markedly to increased soil $\mathrm{Na}$ $\mathrm{HCO}_{3}-\mathrm{P}$ at low P levels. The $\mathrm{P}$ test level critical for optimum yields, tissue $\mathrm{P}$ concentration, and $\mathrm{P}$ uptake was $\approx 18 \mathrm{mg} \mathrm{P} / \mathrm{kg}$ for both grasses.

Bentgrass had slightly higher tissue $\mathrm{P}$ concentrations and total P uptake (Fig. 1 B,C) than annual bluegrass at similar soil test levels. The tissue $\mathrm{P}$ and $\mathrm{P}$ uptake averaged across the soil $\mathrm{NaHCO}_{3}-\mathrm{P}$ levels were $1.78 \mathrm{mg} \mathrm{P} /$ $\mathrm{g}$ and $1.18 \mathrm{mg} \mathrm{P}$ per pot, respectively, for bentgrass as opposed to $1.48 \mathrm{mg} \mathrm{P} / \mathrm{g}$ and $0.80 \mathrm{mg} P$ per pot for annual bluegrass. The result indicates that bentgrass is more capable than annual bluegrass of absorbing $\mathrm{P}$ in acidic soils. However, the relative growth response of the grasses to $\mathrm{P}$ fertilization needs to be determined when the species are mixed.

\section{Literature Cited}

Cate, R.B. and L.A. Nelson. 1965. A rapid method for correlation of soil test analysis with plant response data. North Carolina Agr. Expt. Sta. Intl. Soil Testing Ser. Technol. Bul. 1.

Goss, R.L., S.E. Brauen, and S.P. Orton. 1975. The effects of N, P, K, and S on Poa annua L. in bentgrass putting green turf. J. Sports Turf Res. Inst. 51:74-82.

Hall, J.R. and R.W. Miller. 1974. Effect of phosphorus, season and method of sampling on foliar analysis of Kentucky bluegrass, p. 155-171. In: E.C. Roberts (ed.) Proc. 2nd Intl. Turfgrass Res. Conf., Blacksburg, Va., 17-21 June 1973, Amer. Soc. Agron. and Crop Sci. Soc. Amer., Madison, Wis.

Khalid, R.A., W.H. Patrick, Jr., and R.D. Delaune. 1977. Phosphorus sorption characteristics of flooded soils. Soil Sci. Soc. Amer. J. 41:305-310.

Murphy, J. and J.P. Riley. 1962. A modified single solution method for the determination of phosphate in natural waters. Anal. Chim. Acta 27:31-36.

Olsen, S.R. and L.E. Sommers. 1982. Phosphorus, p. 403-430. In: A.L. Page et al. (eds.). Methods of soil analysis. part 2. Agronomy 9. Amer. Soc. Agron., Madison, Wis. 